RESEARCH ARTICLE

Seaweed resources of Kerala coast and its economic potential

S.K. YADAV\#, M. PALANISAMY* \& G.V.S. MURTHY

Botanical Survey of India, Southern Regional Centre, T.N.A.U. Campus, Coimbatore - 641003

Abstract

Marine macro algae, popularly known as seaweeds, are one of the most important marine natural resources and used as raw material for the production of phytochemicals, food products and in various industries. More than 20,000 seaweeds are distributed throughout the world, of which only 221 (1.1\%) are commercially utilized, which includes 145 species for food and 110 species for phycocolloid production (Sahoo, 2000). During our present work, a comprehensive survey of the Kerala coast have been carried out between 2011-2015 and a total of 147 taxa of seaweeds including 42 economically important species have been enumerated from Kerala coast. The economic prospects of seaweed resources of Kerala are discussed in the present study in order to highlight the potentiality of these resources for future demands.

Keywords: Seaweeds, Kerala coast, Economic, Resources.

\title{
Introduction
}

India, being one of the megadiverse countries in the world, has a coastline of about 7500 $\mathrm{km}$ length and harbours about 865 taxa of seaweeds (Rao \& Gupta, 2015). Kerala, located in the south west coast of India, has a coastline of about $580 \mathrm{~km}$ length and geographically lies between $8^{\circ} 18^{\prime}-12^{\circ} 48^{\prime} \mathrm{N}$ latitude and $74^{\circ} 52^{\prime}-77^{\circ} 22^{\prime} \mathrm{E}$ longitude. The coastline is remarkably straight and is interrupted by natural rocky landscapes and artificially laid stones, beaches, cliffs, rivers, estuaries and backwaters at many places, which support the luxuriant growth of several sea- weeds. However, there no any comprehensive survey of the coast and only sporadic reports are available in literature (Nair \& al. 1982, 1986a, b; Sobha \& Nair, 1983; Chennubhotla \& al. 1988; Mathew, 1991; Kalia- perumal \& Chennubhotla, 1997; Sulekha \& Panikkar, 2006). Therefore, we have carried out comprehensive survey of the entire Kerala coast in all the seasons for a period of 4 years between 2011-15 to primari- ly document the seaweed diversity and to review the prospects of these promising marine resources for its further utilisation for human being.

Methods

The present work is mainly based on the fresh collection of seaweeds from the Kerala coast and a thorough scrutiny of the relevant literature. During the years 2011-2015, 8 field tours were conducted in all the seasons. Totally 149 sites were surveyed and collected 1272 field numbers of seaweeds in du- plicate. The original field photographs showing the 
habits and habitats of seaweeds were taken using the underwater (Olympus) and digital cameras (Nikon COOLPIX L120) and geo locations of the collection sites were recorded using portable GPS (Garmin 12 channels). The seaweed samples were collected ran- domly from the intertidal regions, thoroughly washed and herbarium sheets were prepared for each species and the representative samples were preserved in $4 \%$ formalin solution. All the wet and dry specimens were examined carefully under the light and com- puter attached stereo microscopes (NIKON SMZ1500 and NIKON ECLIPSE 50i)and identified following the standard available literatures (K.S. Srinivasan, 1969, 1973; Desikachary \& al., 1990, 1998; Silva \& al., 1996; Krishnamurthy, 2000; Jha \& al., 2009; Krishnamurthy \& Baluswamy, 2010; Kraft, 2007, 2009; Huisman, 2015) and online resources such as Algaebase, (www. algaebase.org), WoRMS (www.marinespecies.org), Macroalgal Herbarium Portal (macroalgae.org), Inter- national Phycological Society (www.intphycsoc.org/) etc. All the wet and dry herbarium specimens are de- posited at Madras Herbarium (MH), Botanical Survey of India,Coimbatore.

Results and Discussion

A total of 147 taxa (including varieties and for- ma) of seaweeds were recorded from the Kerala coast, which accounts about $17 \%$ of the Indian seaweeds. The enumeration includes 48 taxa of Chlorophyceae, 43 taxa of Phaeophyceae and 56 taxa of Rhodophyce- ae (Table 1). Among these, the class Rhodophyceae is dominant with $38 \%$, followed by Chlorophyceae with 33\% and Phaeophyceae with $29 \%$ of total number 


\begin{tabular}{|l|l|l|l|l|l|l|}
\hline \multicolumn{2}{|c|}{ Table 1.Summary of taxonomic account of seaweed enumerated in Kerala coast. } \\
\hline SI. No. & Class & $\begin{array}{l}\text { Orde } \\
\mathrm{r}\end{array}$ & $\begin{array}{l}\text { Famil } \\
\text { y }\end{array}$ & $\begin{array}{l}\text { Genu } \\
\text { s }\end{array}$ & $\begin{array}{l}\text { Speci } \\
\text { es }\end{array}$ & $\begin{array}{l}\% \text { value } \\
\text { of } \\
\text { specie } \\
\text { s }\end{array}$ \\
\hline & Chlorophyceae & 6 & 9 & 16 & 48 & $\begin{array}{l}33 \\
\%\end{array}$ \\
\hline & Phaeophyceae & 5 & 7 & 17 & 43 & $\begin{array}{l}29 \\
\%\end{array}$ \\
\hline Total & Rhodophyceae & 10 & 18 & 28 & 56 & $\begin{array}{l}38 \\
\%\end{array}$ \\
\hline
\end{tabular}

of seaweeds. The number of seaweed taxa recorded here is the highest as compared to the previous re- ports.

The result also shows that the maximum diversity of seaweeds was recorded during the postmonsoon season whereas 34 species were found throughout the year. During the monsoon and post-monsoon sea- sons, Chlorophyceae shows the highest diversity (14 species), followed by Rhodophyceae (10 species) and Phaeophyceae (6 species). It is also revealed that out of 147 taxa, 19 taxa were found common, whereas 37 taxa were distributed moderately and 92 taxa were rare or very scanty in distribution (Table 2). Species like Centrocersa clavulatum, Chaetomorpha anten- nina, Cladophora vagabunda, Enteromorpha com- pressa, E. flexuosa, E. prolifera, Gelidiopsis variabilis, Gelidium micropterum, Gracilaria corticata, Grate- loupita filicina, G. lithophila, Padina tetrastromatica, Hypnea musciformis, Sargassum tenerrimum, Ulva fasciata etc. were found widely distributed in Kerala coast. Similarly, species like Acanthophora spicifera, Bryopsis pinnata, B. plumosa, Caulerpa peltata, C. racemosa, C. taxifolia, Chaetomorpha linum, Chond- racanthus acicularis, Dictyota dichotoma, Gelidium

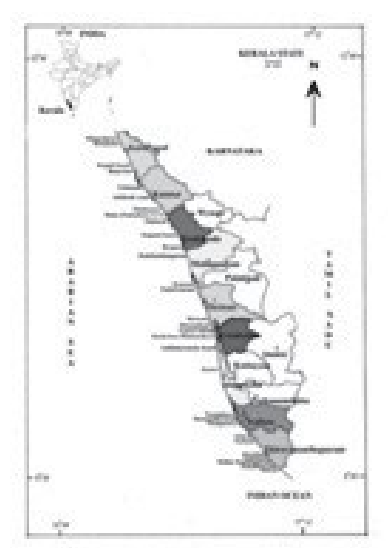


pusillum etc. were moderately distributed at most of the places. Whereas species like Bostrychia tenel- la, Champia compressa, Caulerpa scalpelliformis, C. sertularioides, Dictyopteris delicatula, Enteromorpha linza, Gelidiella acerosa, Struvea anastomosans, Ulva reticulate etc. were found very scantily distributed. The rich diversity and luxuriant growth of seaweeds were recorded atMullurkadalapuram, Vizhinjam, Kovalam, Varkala, Edava, Thangassery, Thirumulla- varam, Baypore, Thikkodi, Mahe, Ezhimala, Manjesh- war and Hosabettu coasts.

\section{Economical prospective}

Seaweeds are the marine renewable natural re- source and have the potential to be utilised in vari- ous ways such as food (in the form of recipes, salads, soups, jellies and vinegar), fodder, fertilisers (SLF), Biofuels, and in various industries. Since ancient times, they are used as food in various forms, espe- cially in South East Asian countries (Japan, China, Ko- rea, Indonesia) and Pacific (Hawaii). Presently, there are 42 countries in the worldwide with reports of commercial exploitation of seaweeds. Among them, China holds first, followed by North Korea, South Ko- rea, Japan, Philippines, Chile, Norway, Indonesia, USA and India. These top 10 countries of the world con- tribute up to $95 \%$ of the world's commercial seaweed utilization (Khan \& Satam, 2003). According to Braune \& Guiry (2011), seaweeds like Porphyra for Nori, Lam- 


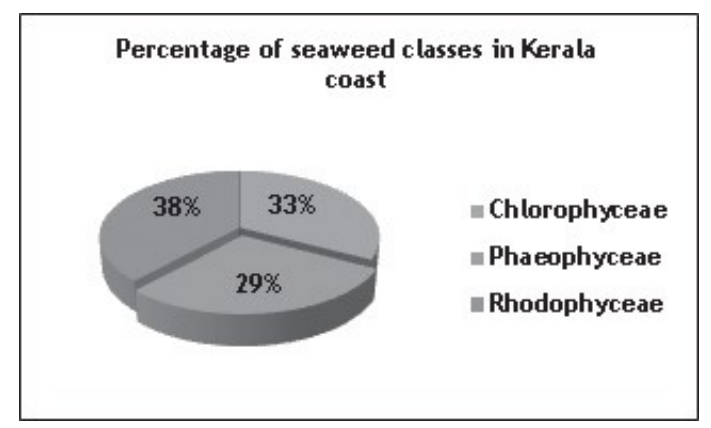

\begin{tabular}{|c|c|c|c|c|}
\hline Class & $\underset{n}{\text { Commo }}$ & $\begin{array}{c}\text { Moderat } \\
\mathrm{e}\end{array}$ & Rare & $\begin{array}{l}\text { Total no. } \\
\text { of } \\
\text { species }\end{array}$ \\
\hline Chlorophyceae & 7 & 12 & 29 & 48 \\
\hline Phaeophyceae & 4 & 7 & 32 & 43 \\
\hline Rhodophyceae & 8 & 17 & 31 & 56 \\
\hline Total & 19 & 36 & 92 & 147 \\
\hline
\end{tabular}

inaria for Kombu, Undaria for Wakame are cultivated on large scale and annually harvested a quantity of about 400,000 tons.

The utilization of seaweed resources plays an important role in supporting the economy in many parts of the world. However, In India, the attention in this regard is drawn only in the recent years (Chen- nubhotla \& al., 2013a \& b). Only experimental scale cultivation of commercially important seaweeds such as Gelidiella acerosa, Gracilaria edulis, Hypnea musciformis, Acanthophora spicifera and Sargassum spp. using various culture techniques have been carried out successfully (Kaliaperumal, 2005). Many of the maritime states of India have not been surveyed in- tensively, which is a prerequisite for its proper utiliza- tion. In the east coast of India, particularly in the Gulf of Mannar region of Tamil Nadu, the local people have started the large scale collection and artificial cultiva- tion of several economically important seaweeds and getting revenue by selling dry seaweeds @ ₹ 8-25/ kg (Times of India, 25 Dec., 2014). Recently Central Salt and Marine Chemicals Research Institute (CSMCRI), Bhavnagar, Gujarat has produced ethanol from the fresh biomass of red seaweed species Kappaphycus alvarezii (Khambaty \& et al., 2012).

Among the 147 species of seaweeds document- ed from Kerala coast, 42 species are economically important (Table 3 ) based on the review of literature (Yadav \& al., 2015). Of these 42 species, 29 species are edible, 24 species are suitable for industrial sectors to extract the phycocolloides (agar-agar, agaroids, algin, carageenans etc.), 14 species used as fodder for domestic animals, 11 species for the production of ma- nures in the form of Seaweeds Liquid Fertilizers (SLF) and 7 species suitable for various medicinal purposes. The Rhodophyceae is dominant (19 taxa), followed by Chlorophyceae (14 taxa) and Phaeophyceae (9 taxa). Although, the abundance of seaweed diversity in Ker- ala is less as compared to the other maritime states 
like Tamil Nadu, Gujarat etc. and presently it cannot support any seaweed based large industries. However attempts should be made by the entrepreneurs and concerned authority to support the coastal villagers for making awareness and large scale artificial culti- vation of commonly growing seaweeds at places with rich diversity of seaweeds and establish seaweeds based industries which can serve as an additional source of income for local people.

Conclusion

Seaweeds are one of the most important marine natural resources, contrary to its name as 'weed'. First of all, awareness should be created among the coast- al villagers regarding the direct uses of seaweeds as food (in the form of salad, soup, jellied etc.), indus- tries (pharmaceuticals, textile, cosmetics, painting, manures, fertilizers etc.) and for cattle feed. For con- tinuous supply of raw materials, large scale cultivation should be promoted which will improve the financial status of the local people by providing employment. The economically important seaweed cultivations boom to the fishery villagers.

References

Braune, W. \& M. D. Guiry, 2011. Seaweeds, A colour guide to common benthic green, brown and red algae of the world's oceans. A.R.G. GantnerVerlag K.G., Rug- gell, Liechtenstein, Germany. 601.

Chennubhotla, V.S.K., B.S. Ramachandrudu, P. Kaladharan \& S.K. Dharmaraja, 1988. Seaweed resources of Kerala coast. Bull. Aqua. Biol.7:

$69-74$

Chennubhotla, V.S.K., M. Umamaheswara Rao \& K.S. Rao, 2013a. Exploitation of marine algae in Indo-Pacific region. Seaweed Res. Utiln., 35 (1\&2): 1-7.

Chennubhotla, V.S.K., M. U. Rao \& K.S. Rao, 2013b.Commer- cial importance of marine macro algae. Seaweed Res. Utiln., 35 (1\&2): 118-128.

Desikachary, T.V., V. Krishnamurthy \& M.S. Balakrishnan, 1990, 1998.Rhodophyta Vols. I \& II. Madras Science Foundation, Chennai. 
Huisman, J.M., 2015. Algae of Australia: Marine Benthic Al- gae of North-

wesetrn Australia, 1: Green andBrown Algae. CSIRO Publishing, Melbourne. Australia.

Jha, B., C.R.K. Reddy, M.K. Thakur \& M.U.Rao, 2009.Sea- weeds of India.The diversity and distribution of Sea- weeds in Gujarat Coast.CSMCRI, Bhavnagar. 215.

Kaliaperumal, N, 2005. Prospects of seaweed farming in In- dia. Proc. Ocean Life, Food Medicine Expo. 384- 393.

Kaliaperumal, N. \& V.S.K. Chennubhotla, 1997. Seaweed distribution and resources in Kerala coast. Seaweed Res. Utiln. 9 (1\&2): 29-32.

Kaliaperumal, N., S. Kaliamuthu \& J.R. Ramalingam, 1995. Economically Important Seaweeds. CMFRI special publication, 62: 1-35.

Khambaty, Y., K. Mody, M. R. Gandhi, S. Thampy, P. Maiti, H. Bhrahmbhatt, K. Eswaran \& P.K. Ghosh. 2012.Kap- paphycus alvarezii as a source of bioethanol. Biore- source Technol., 103 (1): 180-185.

Khan, Sajid I. \& S.B. Satam, 2003. Seaweed Mariculture: scope and potential in India. Aquaculture Asia, 4 (4): 26-28.

Kraft, G. T., 2007, 2009.Algae of Australia: Marine Benthic Algae of Lord Howe Island and the SouthernGreat- Barrier Reef, 1: Green Algae; 2. 2: Brown Algae.CSIRO Publishing, Melbourne, Australia.

Krishnamurthy, V. 2000. Algae of India and neighbouring countries I. Chlorophycota; Oxford \& IBH Publishing Co. Pvt. Ltd., New Delhi. 210.

Krishnamurthy, V. \& M. Baluswami, 2010.Phaeophyceae of India and neighbourhood.Vol.I, Krishnamurthy Insti- tute of Algology, Chennai. 192.

Kumar, R.A.S. \& R.S. Bai, 2008. Effect of aqueous extracts of seaweeds and seagrass on amylase activity in Zea mays L. var Pioneer. Seaweed Res. Utiln., 30: 259- 262.

Manilal, A., J. Selvin, S. Sujith, G.S. Kiran \& M.V.N. Panikkar, 2012.Evaluation of therapeutic efficiency of Indi- an alga Acrosiphonia orientalis (J. Agardh) P.C. Silva in the treatment of Vibriosis in Penaeusmonodon. Thalassas, 28 (1): 33-46.

Manilal, A., S. Sujith, B. Subarathnam, G. SeghalKiran, Jo- seph Selvin, ChippuShakir\& Aaron Premnath Lipton, 2010. Bioactivity of the Red algae Asparagopsis taxi- formis collected from the south western coast of Ker- ala. Braz. J. Oceanography, 58 (2): 93100.

Mathew, S. S., 1991. Some Observations on the Ecology and Biochemical Aspects of the Seaweeds ofKerala Coast. Ph.D. thesis.Cochin University of Science and Tech- nology, Kochi, India.[Unpublished].

Nair, B. N., V. Sobha \& M. Arunachalam, 1982. Algae from southern Kerala coast. Indian J. Mar.Sci.11 (3): $266-26$.

Nair, B. N., V. Sobha, R. Chandran, M. Rathiammal, P. I. Mi- randa, S. Maya \& H. Suryanarayanan,1986a. Algal re- sources of Kerala coast II. An up-to-date list of Indian marine algae. Aquat.Biol. 6:25-52.

Nair, B. N., V. Sobha, R. Chandran, P.A. Paul, P.I. Miranda \& H. Suryanarayanan. 1986b. Nature and distribution of the littoral algae and seagrasses of the southwest coast of India. Proc. Indian Nation.Sci. Acad., Part B, Biol. Sci. 52: 733-744.

Pramitha, V.S. \& A.P. Lipton, 2013.Antibiotic potentials of red macroalgae Hypnea musciformis (Wulfen) Lam- ouroux and Hypnea valentiae (Turner) Mont. Seaweed Res. Utiln., 35 (1\&2):95-107.

Rao, P.S.N. \& R.K. Gupta, 2015. Algae of India, Vol 3: A checklist of Indian Marine Algae (Excluding Diatoms \& Dinoflagellates). Botanical Survey of India, Kolkata. pp 93.

Sahoo, D., 2000.Farming the Ocean - Seaweeds cultivation and utilization.Aravali Books International (P.) Ltd., New Delhi. pp. 44.

Sahu, Nivedita \& C. Ganesh Kumar, 2014. Characterization of isolated Polysaccharide and biochemical ttributes of red algae, Grateloupia filicina. International Jour- nal of Science and Research, (3): 960-963.

Shynu, S.P., S. Shibu \& V. Jayaprakash. 2014. The economical- ly valuable seaweeds of Thirumullavaram, southwest coast of Kerala. J. Aquat. Biol.Fish.2(1): 233-237.

Sobha, V., S. Santhosh, G. Ghita \& E. Valsalakumar, 2008. Food products from seaweeds of south Kerala coast. Seaweed Res. Utiln.30(1\&2): 199-2003.

Sobha.V \& N. B. Nair, 1983. Marine algae of Southwest coast of India. In: 
Krishnamurthy, V. (ed.), Marine Plants.17-24.

Srinivasan, K.S. 1969, 1973.Phycologialndica. (Icones of In- dian marine algae) Vols. I \& II. Botanical Survey of India, Calcutta.

Sulekha, S. \& M.V.N. Panikkar, 2006. Marine green algal flora of Kollam Coast, Kerala, South India. Seaweed Res. Utiln. 28(1): 5-21.

The Times of India, Times Nation, 13, published On

25 Dec. 2014 (http://epaperbeta.timesofind-

ia.com/Article.aspx?eid=31804\&articlexml=- Women-dive-deep-to-weedout-gender-barri- er-25122014013012)

Yadav, S.K., M. Palanisamy \& G.V.S. Murthy, 2015. Econom- ically important seaweeds of Kerala coast, India - A Review. Elix. Biosci.82: 32147-32152. (http://www.

elixirpublishers.com).

Table 3: List of the economically important seaweeds of Kerala coast, India.

\begin{tabular}{|c|c|c|c|}
\hline $\begin{array}{ll}\text { Sl. } \\
\text { No. }\end{array}$ & Name of the taxa & Uses & References \\
\hline \multicolumn{4}{|c|}{$\begin{array}{ll}\text { CHLOROPHYCEAE } \\
\end{array}$} \\
\hline & $\begin{array}{l}\text { Enteromorpha compressa (L.) } \\
\text { Nees }\end{array}$ & $\begin{array}{l}\text { Edible, Fodder, } \\
\text { Medicinal }\end{array}$ & $\begin{array}{l}\text { Kaliaperumal \& al., 1995; Shynu } \\
\text { \& al., } 2014\end{array}$ \\
\hline & Ulva fasciata Delile & $\begin{array}{l}\text { Edible, Fodder, } \\
\text { Medicinal }\end{array}$ & $\begin{array}{l}\text { Sobha\& al., 2008; Shynu\& al., } \\
2014\end{array}$ \\
\hline & Ulva lactuca L. & $\begin{array}{l}\text { Edible, Fodder, } \\
\text { Medicinal, Manure }\end{array}$ & Shynu \& al., 2014 \\
\hline & Ulva reticulata Forssk. & Edible & $\begin{array}{l}\text { Sobha \& al., 2008; Kaliaperuma } \\
\& \text { al., } 1995\end{array}$ \\
\hline & Ulva rigida C.Agardh & Edible & $\begin{array}{l}\text { Kaliaperumal \& al., 1995; Shynu } \\
\& \text { al., } 2014\end{array}$ \\
\hline & $\begin{array}{l}\text { Ulva quilonensis } \\
\text { Sindhu\&Panikkar }\end{array}$ & $\begin{array}{l}\text { Edible, Fodder, } \\
\text { Medicinal }\end{array}$ & $\begin{array}{l}\text { Kaliaperumal \& al., 1995; Shynu } \\
\text { \& al., } 2014\end{array}$ \\
\hline & $\begin{array}{l}\text { Acrosiphonia orientalis(J. } \\
\text { Agardh) P.C. Silva }\end{array}$ & Medicinal & Manilal \& al., 2012. \\
\hline & $\begin{array}{l}\text { Cladophora prolifera(Roth) } \\
\text { Kutz. }\end{array}$ & Edible, Fodder & Shynu \& al., 2014 \\
\hline & $\begin{array}{l}\text { Cladophora fascicularis (G. } \\
\text { Mertens ex C.Agardh) Kutz. }\end{array}$ & Edible, Fodder & $\begin{array}{l}\text { Kaliaperumal \& al., 1995; Shynu } \\
\text { \& al., } 2014\end{array}$ \\
\hline & $\begin{array}{l}\text { Bryopsis plumosa(Huds.) C. } \\
\text { Agardh }\end{array}$ & $\begin{array}{l}\text { Edible, Fodder, } \\
\text { Manure }\end{array}$ & Shynu \& al., 2014 \\
\hline & Caulerpa peltata J.V. Lamour. & $\begin{array}{l}\text { Edible, Fodder, } \\
\text { Manure }\end{array}$ & Shynu \& al., 2014 \\
\hline & $\begin{array}{l}\text { Caulerpa racemosa (Forssk.) } \\
\text { J. Agardh }\end{array}$ & Edible & $\begin{array}{l}\text { Kaliaperumal \& al., 1995; Sobha } \\
\& \text { al., } 2008\end{array}$ \\
\hline & $\begin{array}{l}\text { Caulerpa sertularioides (S.G. } \\
\text { Gmel.) M. Howe }\end{array}$ & $\begin{array}{l}\text { Edible, Fodder, } \\
\text { Manure }\end{array}$ & $\begin{array}{l}\text { Kaliaperumal \& al., 1995; Shynu } \\
\text { \& al., } 2014\end{array}$ \\
\hline & $\begin{array}{l}\text { Caulerpa taxifolia (Vahl) C. } \\
\text { Agardh }\end{array}$ & $\begin{array}{l}\text { Edible, Fodder, } \\
\text { Manure }\end{array}$ & Shynu \& al., 2014 \\
\hline \multicolumn{4}{|c|}{ PHAEOPHYCEAE } \\
\hline & $\begin{array}{l}\text { Dictyopteris bartayresiana } \\
\text { J.V. Lamour. }\end{array}$ & $\begin{array}{l}\text { Edible, Fodder, } \\
\text { Medicinal, Manure }\end{array}$ & Shynu \& al., 2014 \\
\hline & $\begin{array}{l}\text { Lobophora variegata (J.V. } \\
\text { Lamour.) Womersley ex E.C. } \\
\text { Oliveira }\end{array}$ & Industrial & Shynu \& al., 2014 \\
\hline & $\begin{array}{l}\text { Padina gymnospora (Kutz.) } \\
\text { Sond. }\end{array}$ & $\begin{array}{l}\text { Edible, Fodder, } \\
\text { Industrial, Manure }\end{array}$ & Shynu \& al., 2014 \\
\hline & $\begin{array}{l}\text { Padina tetrastromatica } \\
\text { Hauck }\end{array}$ & $\begin{array}{l}\text { Edible, Fodder, } \\
\text { Industrial, Manure }\end{array}$ & $\begin{array}{l}\text { Sobha \& al., 2008; Shynu \& al., } \\
2014\end{array}$ \\
\hline
\end{tabular}




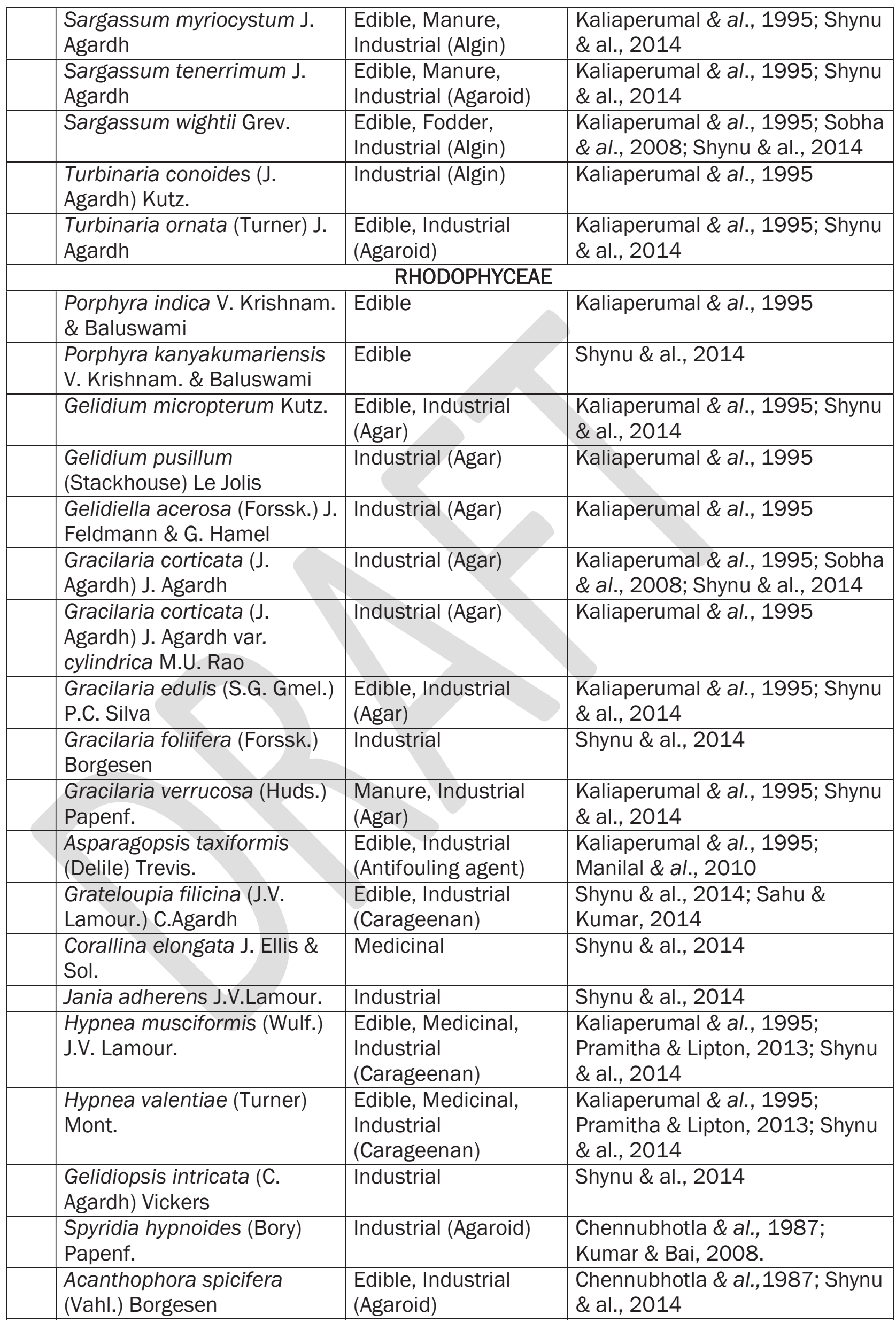

